\title{
DETERMINATION OF SOME BIOGENIC AMINES LEVELS IN SOME CHEESE VARIETIES
}

\author{
WALAA M. ELKASSAS and ENGY FAWZY ELBAHY \\ Department of Food Hygiene, Animal Health Research Institute, Egypt.
}

Received: 31 December 2015; Accepted: 27 January 2016

\begin{abstract}
Biogenic amines are nitrogenous compounds that posses biological activity. The source of its production is the microbial decarboxylation of amino acids. These compounds are found in various types of cheeses. The aim of this work was to determine the concentration of biogenic amines (histamine, tyramine and cadaverine) in some Egyptian cheese varieties. Sixty samples of Ras, Cheddar and Gouda cheeses (20 each) were collected randomly from hyper-markets and small-markets in Kafrelsheikh Governorate. The concentration of biogenic amines was assayed by using high performance liquid chromatography (HPLC). Tyramine was the most biogenic amine formed at high concentration in Ras cheese of both hyper and small-markets (total mean, $20.67 \pm 3.84 \mathrm{mg} / 100 \mathrm{~g}$ ) followed by histamine (total mean, $16.27 \pm 3.03 \mathrm{mg} / 100 \mathrm{~g}$ ) and cadaverine (total mean, $12.23 \pm 2.49 \mathrm{mg} / 100 \mathrm{~g}$ ). While Cheddar cheese followed by Gouda cheese showed concentrations of the examined biogenic amines lesser than that of Ras cheese. Matching these levels with the recommended standard by FDA (2001), high levels of biogenic amines in the examined cheese varieties exceeded the permissible value $(10 \mathrm{mg} / 100 \mathrm{~g})$ where $70 \%$ (each); 70, 80 and 50, 60\% of hyper and small-markets Ras cheese samples were exceeded FDA permissible value for histamine, tyramine and cadaverine, respectively and cheddar cheese samples of hyper and small markets showed 50\% (each); 50, 60 and 30, 40\% were exceeded the permissible value, respectively, while 20 , 40; 30, 50 and 30, 40\% for hyper and small markets Gouda cheese samples, respectively, which poses a threat to public health. The public health importance of these biogenic amines was discussed and the recommendations were put.
\end{abstract}

Key words: Cheese, Histamine, Tyramine, Cadaverine

\section{INTRODUCTION}

Milk and milk products are very important in human nutrition and, among them; cheese is considered a good source of protein, vitamins and minerals. However, cheese is one of the most fermented foods commonly associated with biogenic amines (BAs) contamination. BAs are low molecular weight nitrogenous compounds that possess biological activity and are mainly produced by microbial decarboxylation of amino acids, particularly histidine, tyrosine, lysine, ornithine and arginine (Halász et al., 1994).

Biogenic amines are compounds commonly present in living organisms in which they are responsible for many essential functions. They can be naturally present in many foods such as fruits and vegetables, meat, fish, chocolate and milk, but they can also be produced in high amounts by microorganisms through the activity of amino acid decarboxylases

Corresponding author: Dr. WALAA M. ELKASSAS

E-mail address: w.elkasas@yahoo.com

Present address: Department of Food Hygiene, Animal Health Research Institute, Egypt.
(Ten Brink et al., 1990). The presence of BAs in foods is of great interest not only due to their possible toxicity, but also can be used as indicators for quality of freshness or spoilage of foods (Awan et al., 2008). These compounds include histamine, tyramine, cadaverine, putrescine, tryptamine and 2-phenylethylamine, that have been found in various types of cheeses (Silla, 1996). Cheese provides an ideal environment for the production of BAs but amine concentration differs widely and depends on several factors, such as, cheese variety, storage temperature, ripening time and microbial population (Vale and Gloria, 1997). Meanwhile, other factors such as, level of proteolysis (availability of free amino acids), $\mathrm{pH}$, water activity, salt-in-moisture level, bacterial counts and synergistic effect between micro-organisms have large effect on production and accumulation of BAs (Gardini et al., 2001). The amine-producing ability of various bacteria differ widely. The presence of microorganisms that have amino acid decarboxylase activity, such as lactobacilli, enterococci, micrococci and many strains of enterobacteriaceae, are necessary for production of BAs (Suzzi and Gardini, 2003). Enterobacteriaceae, enterococci and coliforms are often responsible for production of BAs in cheese especially when their counts exceed $10^{6} \mathrm{cfu} / \mathrm{g}$ (Sharaf 
et al., 1997). Tyramine and histamine are the most abundant and frequent BAs in cheese (Fernández et al., 2007).

Some BAs have been proposed as indicators of the quality of foodstuffs (Maria et al., 2000). The consumption of foods with high levels of BAs may cause several problems such as nausea, respiratory disorders, hot flushes, sweating, heart palpitation, headache, bright red rash, oral burning, hypo- or hypertension, whose intensity are depended on quantitative and qualitative differences (Stratton et al., 1991).

Physiologically, histamine is one of the most effective BAs, it has vasoactive and psychoactive effects (Repka-Ramírez and Baraniuk, 2002). Moreover, it is the main BAs involved in food poisoning and it is limited in some foodstuffs by law. At non-toxic doses, food borne histamine can cause intolerance symptoms such as diarrhoea, hypotension, headache, pruritus and flushes. Just $75 \mathrm{mg}$ of histamine, a quantity commonly present in some meals, can induce symptoms in the majority of healthy persons with no history of histamine intolerance (Wöhrl et al., 2004). Tyramine can act as a vasoconstrictor which increases the noradrenaline concentration in the blood that leads to hypertension, migraine, brain hemorrhage, and heart failure. Cadaverine is also given much attention as these amines can be precursors of carcinogenic nitrosamines which cause cancer in humans (Muñoz, 2008 and Elsanhoty et al., 2009).

Different research institutes around the world have set legal limits for biogenic amine content of food products to ensure safety of consumers. The Nutritional Codex of the Slovak Republic has set the legal limit for histamine and tyramine in fish and fish products at $200 \mathrm{mg} / \mathrm{kg}$. The same agency set the legal limit for tyramine in cheese at $200 \mathrm{mg} / \mathrm{kg}$. The histamine limit in fish set by the Codex Alimentarius Commission is $200 \mathrm{mg} / \mathrm{kg}$. Next to fish, cheese is the most implicated item associated with biogenic amine food poisonings (Maijala and Erola, 2003). It has been observed that the ripening process (involving proteolysis) in cheese contributes to an increase in the amino acid availability and that cheeses with long ripening periods contained high BAs concentrations (Fernández et al., 2007).

Therefore, this study was undertaken to determine the concentration of some biogenic amines (histamine, tyramine and cadaverine) in some cheese varieties (Ras, Cheddar and Gouda) collected from hypermarkets and small markets in Kafrelsheikh Governorate and match these levels with the regulatory specifications to determine their quality.

\section{MATERIALS and METHODS}

\section{Samples:}

A total of 60 random samples of different kinds of cheese (Ras, Cheddar and Gouda) (20 samples each) were collected from hyper-markets and small markets in Kafrelsheikh Governorate, Egypt to determine their contents of biogenic amines.

Biogenic amines included histamine, tyramine and cadaverine were estimated by High Performance Liquid Chromatography (HPLC) according to the technique adopted by Krause et al. (1995) and Pinho et al. (2001).

\section{Reagents preparation:}

1. Dansyl chloride solution: 500mg of dansyl chloride were dissolved in $100 \mathrm{ml}$ acetone.

2. Standard solutions: Stock standard solutions of the tested amines were prepared as the following: add 25 $\mathrm{mg}$ of each standard pure amine (histamine- $2 \mathrm{HCl}$, tyramine - $2 \mathrm{HCl}$ and cadaverine- $2 \mathrm{HCl}$ ) were dissolved in $25 \mathrm{ml}$ distilled water individually.

\section{Amine Extraction:}

$25 \mathrm{~g}$ of each cheese sample was blended with $125 \mathrm{ml}$ of 5\% trichloroacetic acid (TCA) for 3 min using a warning blender then filtration was achieved using filter paper Whatman No1. Thus, $10 \mathrm{ml}$ of the filtrate were transferred into a suitable glass tube with $4 \mathrm{~g}$ $\mathrm{NaCl}$ and $1 \mathrm{ml}$ of $50 \% \mathrm{NaOH}$. The filtrate was extracted three times (2min each) by using $5 \mathrm{ml} \mathrm{n}$ butanol: chloroform $(1: 1 \mathrm{v} / \mathrm{v})$ and the upper clear layer was transferred to $100 \mathrm{ml}$ separating funnel by using disposable Pasteur pipette. To combine the organic extracts (upper layer), $15 \mathrm{ml}$ of n-heptane was added in separating funnel and extracted three times with $1.0 \mathrm{ml}$ portions of $0.2 \mathrm{NHCl}$, the $\mathrm{HCl}$ layer was collected in a glass stopper tube. Solution was evaporated just to dryness using water bath at $95^{\circ} \mathrm{C}$ with aid of a gentle current of air.

\section{Formation of dansylamines:}

One hundred $\mu \mathrm{l}$ of each stock standard solution (or sample extract) were transferred to $50 \mathrm{ml}$ vial and dried under vacuum. About $0.5 \mathrm{ml}$ of saturated $\mathrm{NaHCO}_{3}$ solution was added to the residue of the sample extract (or the standard). Vial was stoppered and carefully mixed to prevent loss- due to spattering. Carefully, $1.0 \mathrm{ml}$ dansyl chloride solution was added and mixed thoroughly using vortex mixer. The reaction mixture was kept in water bath at $55^{\circ} \mathrm{C}$ for $45 \mathrm{~min}$. About $10 \mathrm{ml}$ of distilled water were added to the reaction mixture, then vial was stoppered and shaked vigorously using vortex mixer, the extraction of dansylated biogenic amines was carried out using $5 \mathrm{ml}$ of diethyl ether for 3 times again vial was stoppered, shaked for $11 \mathrm{~min}$ and the ether layers were collected in a culture tube using disposable 
Pasteur pipette. The combined ether extracts were carefully evaporated at $35^{\circ} \mathrm{C}$ in dry bath with aid of current air. The obtained dry material was dissolved in $1 \mathrm{ml}$ methanol and $10 \mu \mathrm{l}$ were injected in HPLC.

The concentration of each biogenic amine in the examined samples was recorded as $\mathrm{mg} / 100 \mathrm{~g}$ according to the following formula:

Amine concentration $(\mathrm{mg} / 100 \mathrm{~g})=\underline{\mathrm{C} \times \mathrm{V}}$ $\mathrm{W} \times 10$
Whereas,

$\mathrm{C}=$ Concentration of amine standard $(\mu \mathrm{g} / \mathrm{ml})$

$\mathrm{V}=$ Final dilution of sample extract $(\mathrm{ml})$

$\mathrm{W}=$ Weight of the sample in the final extract $(\mathrm{g})$

Statistical analysis:

The obtained results were statistically evaluated by using analysis of variance (Student t-test) according to Feldmen et al. (2003).

\section{RESULTS}

Table 1: Concentration of histamine $(\mathrm{mg} / 100 \mathrm{~g})$ in the examined cheese samples.

\begin{tabular}{|c|c|c|c|c|c|c|c|}
\hline \multirow[t]{2}{*}{ Sample* } & \multicolumn{3}{|c|}{ Hyper-markets $(n=10)$} & \multicolumn{3}{|c|}{ Small-markets $^{+}(\mathrm{n}=10)$} & \multirow{2}{*}{$\begin{array}{l}\text { Total mean } \\
\qquad(\mathrm{n}=\mathbf{2 0})\end{array}$} \\
\hline & Min. & Max. & Mean \pm SE & Min. & Max. & Mean \pm SE & \\
\hline Ras & 2.2 & 27.9 & $15.18 \pm 2.57$ & 2.8 & 34.1 & $17.35 \pm 3.48$ & $16.27 \pm 3.03^{\mathrm{a}}$ \\
\hline Cheddar & 1.2 & 18.5 & $9.63 \pm 2.1$ & 1.7 & 25.1 & $11.84 \pm 2.65$ & $10.74 \pm 2.38^{b}$ \\
\hline Gouda & 0.5 & 11.2 & $5.89 \pm 1.22$ & 0.8 & 20.3 & $9.64 \pm 2.15$ & $7.77 \pm 1.69^{\mathrm{c}}$ \\
\hline
\end{tabular}

Means with different superscripts $(\mathbf{a}, \mathbf{b}, \mathbf{c})$ were significantly different $(\mathrm{P}<0.05)$.

+ Student t-test indicated significant differences $(\mathrm{P}<0.05)$.

*All examined cheese samples contained histamine (100\%).

Table 2: Concentrations of tyramine $(\mathrm{mg} / 100 \mathrm{~g})$ in the examined cheese samples.

\begin{tabular}{|c|c|c|c|c|c|c|c|}
\hline \multirow[t]{2}{*}{ Sample* } & \multicolumn{3}{|c|}{ Hyper-markets $(n=10)$} & \multicolumn{3}{|c|}{ Small-markets $^{+}(n=10)$} & \multirow{2}{*}{$\begin{array}{l}\text { Total mean } \\
\quad(n=20)\end{array}$} \\
\hline & Min. & Max. & Mean \pm SE & Min. & Max. & Mean \pm SE & \\
\hline Ras & 3.0 & 36.1 & $17.57 \pm 3.36$ & 3.9 & 45.2 & $23.76 \pm 4.31$ & $20.67 \pm 3.84^{\mathrm{a}}$ \\
\hline Cheddar & 1.3 & 21.7 & $10.8 \pm 2.4$ & 2.4 & 29.8 & $14.51 \pm 2.99$ & $12.66 \pm 2.69^{\mathbf{b}}$ \\
\hline Gouda & 0.7 & 16.9 & $7.24 \pm 1.67$ & 1.1 & 23.5 & $11.9 \pm 2.43$ & $9.57 \pm 2.05^{\mathrm{c}}$ \\
\hline
\end{tabular}

Means with different superscripts $(\mathbf{a}, \mathbf{b}, \mathbf{c})$ were significantly different $(\mathrm{P}<0.05)$.

+ Student $t$-test indicated significant differences $(\mathrm{P}<0.05)$.

*All examined cheese samples contained tyramine (100\%).

Table 3: Concentration of cadaverine $(\mathrm{mg} / 100 \mathrm{~g})$ in the examined cheese samples.

\begin{tabular}{|c|c|c|c|c|c|c|c|}
\hline \multirow[t]{2}{*}{ Sample* } & \multicolumn{3}{|c|}{ Hyper-markets $(n=10)$} & \multicolumn{3}{|c|}{ Small-markets $^{+}(\mathrm{n}=10)$} & \multirow{2}{*}{$\begin{array}{l}\text { Total mean } \\
\quad(n=20)\end{array}$} \\
\hline & Min. & Max. & $\operatorname{Mean} \pm$ SE & Min. & Max. & Mean \pm SE & \\
\hline $\operatorname{Ras}$ & 1.6 & 22.7 & $11.49 \pm 2.32$ & 1.9 & 26.4 & $12.96 \pm 2.67$ & $12.23 \pm 2.49^{\mathrm{a}}$ \\
\hline Cheddar & 0.9 & 14.7 & $6.93 \pm 1.44$ & 1.5 & 21.3 & $10.11 \pm 2.33$ & $8.52 \pm 1.89^{b}$ \\
\hline Gouda & 0.5 & 13.3 & $6.8 \pm 1.36$ & 0.6 & 19.7 & $8.49 \pm 2.12$ & $7.65 \pm 1.74^{b}$ \\
\hline
\end{tabular}

Means with different superscripts $(\mathbf{a}, \mathbf{b}, \mathbf{c})$ were significantly different $(\mathrm{P}<0.05)$.

+ Student t-test indicated significant differences $(\mathrm{P}<0.05)$.

*All examined cheese samples contained cadaverine (100\%). 
Table 4: Comparison of biogenic amines levels in cheese varieties with International legislation.

\begin{tabular}{|c|c|c|c|c|c|c|c|c|c|c|c|c|c|}
\hline \multicolumn{14}{|c|}{ Cheese varieties } \\
\hline & & \multicolumn{4}{|c|}{ Ras } & \multicolumn{4}{|c|}{ Cheddar } & \multicolumn{4}{|c|}{ Gouda } \\
\hline & & $\begin{array}{l}\text { Hyper } \\
\text { marke } \\
(n=10\end{array}$ & & & $\begin{array}{l}\text { II- } \\
\text { kets } \\
\text { 10) }\end{array}$ & $\begin{array}{l}\text { Hyp } \\
\text { mar } \\
(n=1\end{array}$ & & $\begin{array}{r}\text { Sm } \\
\text { ma } \\
(\mathbf{n}\end{array}$ & & $\begin{array}{l}\text { Hype } \\
\text { mark } \\
(n=10\end{array}$ & & $\begin{array}{r}\text { Small } \\
(\mathrm{n}=10\end{array}$ & arkets \\
\hline \multirow{2}{*}{$\begin{array}{c}\text { Biogenic } \\
\text { amines }\end{array}$} & \multirow{2}{*}{$\begin{array}{l}\text { Permissible } \\
\text { limit } \\
(\mathrm{mg} / 100 \mathrm{~g}) *\end{array}$} & \multicolumn{12}{|c|}{ No. and \% of samples exceeded permissible limit } \\
\hline & & $\underline{\text { No. }}$ & $\underline{\%}$ & $\underline{\text { No. }}$ & $\underline{\%}$ & No. & $\underline{\%}$ & No. & $\underline{\%}$ & $\underline{\text { No. }}$ & $\underline{\%}$ & No. & $\underline{\%}$ \\
\hline Histamine & 10 & 7 & 70 & 7 & 70 & 5 & 50 & 5 & 50 & 2 & 20 & 4 & 40 \\
\hline Tyramine & 10 & 7 & 70 & 8 & 80 & 5 & 50 & 6 & 60 & 3 & 30 & 5 & 50 \\
\hline Cadaverine & 10 & 5 & 50 & 6 & 60 & 3 & 30 & 4 & 40 & 3 & 30 & 4 & 40 \\
\hline
\end{tabular}

*FDA (2001)

Table 5: Comparison of biogenic amines levels in cheese varieties with Egyptian legislation.

\begin{tabular}{|c|c|c|c|c|c|c|c|c|c|c|c|c|c|}
\hline \multicolumn{14}{|c|}{ Cheese varieties } \\
\hline & & \multicolumn{4}{|c|}{ Ras } & \multicolumn{4}{|c|}{ Cheddar } & \multicolumn{4}{|c|}{ Gouda } \\
\hline & & $\begin{array}{l}\text { Hyper } \\
\text { marke } \\
(n=10\end{array}$ & & & $\begin{array}{l}\text { l- } \\
\text { rets } \\
\text { 0) }\end{array}$ & $\begin{array}{l}\text { Hyp } \\
\text { mar } \\
(n=1\end{array}$ & & $\begin{array}{r}\text { Sm } \\
\text { ma } \\
(\mathbf{n}\end{array}$ & & $\begin{array}{l}\text { Hyp } \\
\text { mar } \\
(n=1\end{array}$ & & $\begin{array}{l}\text { Small- } \\
(\mathrm{n}=10\end{array}$ & arkets \\
\hline \multirow{2}{*}{$\begin{array}{l}\text { Biogenic } \\
\text { amines }\end{array}$} & \multirow{2}{*}{$\begin{array}{l}\text { Permissible } \\
\text { limit } \\
(\mathrm{mg} / 100 \mathrm{~g}) *\end{array}$} & \multicolumn{12}{|c|}{ No. and \% of samples exceeded permissible limit } \\
\hline & & No. & $\underline{\%}$ & $\underline{\text { No. }}$ & $\underline{\%}$ & No. & $\underline{\%}$ & No. & $\underline{\%}$ & No. & $\underline{\%}$ & No. & $\underline{\boldsymbol{q}}$ \\
\hline Histamine & 20 & 3 & 30 & 4 & 40 & - & - & 2 & 20 & - & - & 1 & 10 \\
\hline Tyramine & 20 & 4 & 40 & 6 & 60 & 2 & 20 & 3 & 30 & - & - & 2 & 20 \\
\hline Cadaverine & 20 & 2 & 20 & 2 & 20 & - & - & 1 & 10 & - & - & - & - \\
\hline
\end{tabular}

*EOS (1996)

\section{DISCUSSION}

Cheese represent an ideal environment for amine production but amine concentration varies widely and depends on such factors as cheese variety, age and microflora (Joosten and Van Boekel, 1988). Biogenic amines are valuable to judge the hygienic quality of cheese; therefore they can be used as indicator of food spoilage and can cause toxicological effects to consumers at high levels.

Histamine and tyramine, are the most abundant biogenic amines found in cheeses manufactured from cows' and ewes' milk and usually appear after 30 days of ripening and occur in high levels in mature and in mold-ripened cheeses. Cadaverine has also been detected in large quantities in matured cheeses (Martuscelli et al., 2005).

Results achieved in Table (1) declared that the mean values of histamine concentration $(\mathrm{mg} / 100 \mathrm{~g})$ in Ras, Cheddar and Gouda cheese of hyper and smallmarkets were $15.18 \pm 2.57,17.35 \pm 3.48$ (total mean, $16.27 \pm 3.03$ ); 9.63 $\pm 2.1,11.84 \pm 2.65$ (total, 10.74 \pm

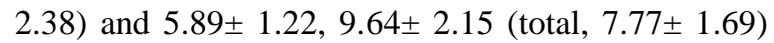
respectively, and all of the examined cheese samples were contained histamine $(100 \%)$. Nearly similar results were recorded by Ekbal and Amer (2010) who found histamine concentration of $17.43 \pm 1.05,12.98 \pm$ 0.81 and $7.65 \pm 0.38 \mathrm{mg} / 100 \mathrm{~g}$ in Ras, Cheddar and Gouda cheese samples, respectively with low incidence than our results $(86.67,73.33$ and $53.33 \%$, 
respectively). The differences between such types of cheese varieties were significant $(\mathrm{P}<0.05)$. Also, significant differences appeared between hyper and small-markets as a result of histamine levels in the examined cheese samples.

El-Zahar (2014) revealed that histamine concentration in Ras cheese samples was ranged from $12 \pm 0.96$ to $26 \pm 2.4 \mathrm{mg} / 100 \mathrm{~g}$ according to ripening/storage period (6-24 months). On the other hand, Ma.Jannine et al. (2012) recorded high levels of histamine concentration $(21.79 \pm 0.1 \mathrm{mg} / 100 \mathrm{~g})$ in Cheddar cheese samples. Lower levels of histamine concentration $(2.901 \mathrm{mg} / 100 \mathrm{~g})$ were recorded by Ahmed (1998) in hard cheese samples collected from Assiut city markets, Egypt.

Inspection of Table (4), it is indicated that $70 \%$ for each hyper and small-markets Ras cheese samples, $50 \%$ for each hyper and small-markets Cheddar cheese samples and 20, 40\% of hyper and smallmarkets Gouda cheese samples, respectively were exceeded the maximum permissible limit of histamine $(10 \mathrm{mg} / 100 \mathrm{~g})$ stipulated by FDA (2001). On the other hand, EOS (1996) recommended a value of $20 \mathrm{mg} / 100 \mathrm{~g}$ to be the safe permissible value of histamine in food, consequently, 30, $40 \%$ of hyper and small-markets Ras cheese; $20 \%$ of small-markets Cheddar cheese and $10 \%$ of small-markets Gouda cheese samples were exceeded such limit of histamine. While Cheddar and Gouda cheese samples of hyper-markets were accepted and within the permissible limit of histamine stated by EOS (1996) (Table, 5).

Önal (2007) demonstrated that the amount of 8-40 $\mathrm{mg} / \mathrm{kg}$ of histamine can cause the mild poisoning, 40 $100 \mathrm{mg} / \mathrm{kg}$ medium poisoning, and the total biogenic amines content over $100 \mathrm{mg} / \mathrm{kg}$ could cause very serious poisoning.

The main symptoms of histamine- rich food is facial flushing, urticaria, edema, diarrhea, stomach ache, cramps, hypotension, anaphylaxis, headache with respiratory disorders (Jarisch, 2004).

Table (2) showed that the mean values of tyramine concentration $(\mathrm{mg} / 100 \mathrm{~g})$ in Ras, Cheddar and Gouda cheese samples of hyper and small-markets were $17.75 \pm 3.36,23.76 \pm 4.31$ (total mean, 20.67 \pm 3.84 ); $10.8 \pm 2.4,14.51 \pm 2.99$ (total mean, $12.66 \pm 2.69$ ) and $7.24 \pm 1.67,11.9 \pm 2.43$ (total mean, 9.57 \pm 2.05 ) respectively, and all of the examined cheese samples were contained tyramine $(100 \%)$. Further, significant differences $(\mathrm{P}<0.05)$ were reported between Ras, Cheddar and Gouda cheese from one side and hyper and small-markets from the other side for tyramine concentrations.
Ekbal and Amer (2010) recorded nearly similar results of tyramine concentration in Gouda cheese $(9.56 \pm 0.72 \mathrm{mg} / 100 \mathrm{~g})$, but Cheddar cheese samples contained high levels of tyramine $(22.12 \pm 1.35$ $\mathrm{mg} / 100 \mathrm{~g}$ ) while Ras cheese contained low levels $(14.95 \pm 0.89 \mathrm{mg} / 100 \mathrm{~g})$ of tyramine concentration than that obtained by our study. Also high levels of tyramine concentration in cheddar cheese $(57.13 \pm 0.2$ $\mathrm{mg} / 100 \mathrm{~g}$ ) were obtained by Ma.Jannine et al. (2012). On the other hand very lower levels of tyramine concentrations $(8.656 \mathrm{mg} / 100 \mathrm{~g})$ in hard cheese samples collected from Assiut city markets, Egypt were recorded by Ahmed (1998).

Tyramine concentration in Ras cheese samples were ranged from $3 \pm 0.28$ to $14 \pm 1.07 \mathrm{mg} / 100 \mathrm{~g}$ according to ripening/ storage period (6-24 months) in a study recorded by El-Zahar (2014).

According to FDA (2001), the maximum permissible limit of tyramine $10 \mathrm{mg} / 100 \mathrm{~g}$, so table (4) revealed that $70,80 \%$ of Ras cheese samples; $50,60 \%$ of Cheddar cheese and 30, 50\% of Gouda cheese samples of hyper and small-markets, respectively were exceeded this limit. While table (5) declared that $40,60 \%$ of Ras cheese samples; $20,30 \%$ of Cheddar cheese samples of hyper and small-markets, respectively and $20 \%$ of Gouda cheese samples of small-markets were exceeded the safe value of tyramine in food $(20 \mathrm{mg} / 100 \mathrm{~g})$ recorded by EOS (1996), while Gouda cheese samples of hypermarkets were compatible with this limit.

In a study of exposure trials with healthy persons and toxicological studies with animals, it was noticed that the intake of 20-100 mg tyramine can cause toxic effect in human, whereas, the outbreak information suggest that the levels of $100-800 \mathrm{mg} / \mathrm{kg}$ tyramine is hazardous (Maijala and Erola, 2002). Hypertension, nausea, sever headache or migraines, emesis, respiratory distress, rashes and increasing the cardiac palpitations are associated with tyramine intoxication (Chiacchierini et al., 2005).

The results obtained in Table (3) revealed that the mean values of cadaverine concentration $(\mathrm{mg} / 100 \mathrm{~g})$ in Ras, Cheddar and Gouda cheese samples of hyper and small-markets were $11.49 \pm 2.32,12.96 \pm 2.67$ (total mean, $12.23 \pm 2.49$ ); $6.93 \pm 1.44,10.11 \pm 2.33$ (total mean, 8.52 \pm 1.89 ) and $6.8 \pm 1.36,8.49 \pm 2.12$ (total mean, 7.65 \pm 1.74 ) respectively, and all of the examined cheese samples were contained cadaverine (100\%). Accordingly, the differences between Cheddar and Gouda cheese samples were not significant.

Low levels of cadaverine in Ras cheese $(8.25 \pm 0.49)$ and Gouda cheese $(4.84 \pm 0.26 \mathrm{mg} / 100 \mathrm{~g})$, while high levels in Cheddar cheese $(10.36 \pm 0.78 \mathrm{mg} / 100 \mathrm{~g})$ samples were obtained by Ekbal and Amer (2010). 
El-Zahar (2014) recorded levels of cadaverine in Ras cheese ranged from $8 \pm 0.71$ to $20 \pm 2.1 \mathrm{mg} / 100 \mathrm{~g}$ according to ripening/storage period (9-14 months). On the other hand, Ma.Jannine et al. (2012) could not be detected cadaverine in Cheddar cheese samples.

From the results obtained in Table (4), we found that $50 \%, 60 \%$ of Ras cheese and $30 \%, 40 \%$ for each Cheddar and Gouda cheese samples of hyper and small-markets, respectively were exceeded the maximum permissible limit of cadaverine $(10 \mathrm{mg} / 100 \mathrm{~g})$ stipulated by FDA (2001). On the other hand, Table (5) revealed that $20 \%$ for each hyper and small-markets Ras cheese samples and $10 \%$ of smallmarkets Cheddar cheese samples were exceeded the safe permissible value of cadaverine in food (20mg/100g) recommended by EOS (1996), while Cheddar cheese samples of hyper-markets and Gouda cheese samples of hyper and small-markets were accepted and within the permissible limit of cadaverine stated by EOS (1996).

Cadaverine can be related to contamination of cheese with species of enterobacteriaceae (Joosten and Northolt, 1987). Although the manufacturing protocol for processed cheese includes high temperature treatment, biogenic amines are not affected by this treatment and are passed from the raw materials (ripened cheese) to the final product (processed cheese), and once biogenic amines are formed, it is difficult to destroy it by pasteurization or cooking (Silla, 1996). Cadaverine intoxication is mainly accompanied with hypotension (Gonzalez de Llano et al., 1998).

From the obtained results, we noticed that tyramine was the most biogenic amine formed at high concentration in the examined cheese samples followed by histamine and cadaverine. Also, cheese samples of small-markets were contained high levels of biogenic amines than that of hyper-markets, this may be related to high storage temperature which may favor the growth of some undesirable bacteria and enhances their decarboxylation activity against the amino acids of cheeses resulting in formation of such biogenic amines.

Also, formation of biogenic amines was affected by ripening period of cheese as longer storage period increases the biogenic amines content. Another factor for biogenic amines formation is the quality of raw milk used for cheese making. Pasteurization of milk eliminates the bacteria responsible for biogenic amines formation. The standardization of milk quality, selection of appropriate starter culture, and hygienic cheese manufacturing will reduce the biogenic amines content in cheese (Elsanhoty et al., 2009). Also, Martuscelli et al. (2005) mentioned that the amount of biogenic amines content in cheese widely varies, and is depended on the type of cheese, the ripening period, the manufacturing process and micro-organisms present.

The production of biogenic amines in cheese has often been linked to non-starter lactic acid bacteria and enterobacteriaceae (Petridis and Steinhart, 1996), some proteolytic bacteria can convert histidine into histamine, however, decarboxylation of lysine into cadaverine by coliforms (Marino et al., 2000) and many enterococci species have the ability to decarboxylate tyrosine into tyramine (Bonetta et al., 2008). So, biogenic amines in food are used as indicator of the hygienic quality of raw materials employed in food manufacture as well as the hygienic quality during food processing (Schneller et al., 1997).

These amines have been studied for their potential risk for human health, since the intake of foods with high biogenic amines loads, or the inadequate detoxification of biogenic amines, can lead to their entering the systemic circulation, inducing the release of adrenaline and noradrenaline and provoking gastric acid secretion, an increased cardiac output, migraine, tachycardia, increased blood sugar levels and higher blood pressure (Shalaby, 1996). Also, they can cause "cheese syndrome" and histamine intoxication which related to tyramine and histamine, respectively. It was observed that histamine at $20 \mathrm{mg} / 100 \mathrm{~g}$ may sufficient to cause the symptoms of scombroid poisoning (CDC, 2000). Approximately, 2-13\% of cheese includes Gouda and Cheddar have been implicated in cases of tyramine and histamine intoxication (Maijala and Erola, 2002).

\section{CONCLUSION}

Biogenic amines play essential roles in the normal development, metabolism and physiological functions of human. However, when ingested in high concentrations, they can cause a range of toxicological effects. Estimation of biogenic amines is important not only from the point of view of their toxicity, but also because they can be used as indicators of the degree of freshness or spoilage of food.

From the obtained results, we concluded that presence of high concentrations of biogenic amines (histamine, tyramine and cadaverine) in Egyptian cheeses reflect the bad hygienic conditions under which they produced and stored especially cheese sold at small markets. Therefore, biogenic amines formation should be controlled by strict use of good hygiene in both raw material and manufacturing environment, with corresponding inhibition of spoilage microorganisms. Accordingly, the permissible levels of biogenic amines stipulated by EOS should be modified to meet the more safe standard adopted by FDA and the levels of biogenic 
amines in different cheeses should be come in accordance with the safe permissible limit recommended by FDA to ensure human safety.

\section{REFERENCES}

Ahmed, M.S. (1998): Evaluation of biogenic amines in some dairy products. M.V.Sc thesis, Fac. of Vet. Med. Assiut Univ. Egypt.

Awan, M.A.; Fleet, I. and Thomas, C.L.P. (2008): Optimising cell temperature and dispersion field strength for the screening for putrescine and cadaverine with thermal desorption-gas chromatography-differential mobility spectrometry. Anal. Chim. Acta. 611(2): 226-232.

Bonetta, S.; Bonetta, S.; Carraro, E.; Coisson, J.D.; Travaglia, F. and Arlorio, M. (2008): Detection of biogenic amine producer bacteria in atypical-Italian goat cheese. J. Food Prot. 71(1): 205-209.

CDC (Centers for Disease Control and Prevention) (2000): Scombroid fish poisoningPennsylvania, 1998. MMWR. 49: 398-400.

Chiacchierini, E.; Restuccia, D. and Vinci, G. (2005): Evaluation of two different extraction methods for chromatographic determination of bioactive amines in tomato products. Talanta. 69 (3): $548-555$

Ekbal, M.A. Ibrahim and Amer, A.A. (2010): Comparison of biogenic amines levels in different processed cheese varieties with regulatory specifications. World J. Dairy and Food Sci. 5(2): 127-133.

Elsanhoty, R.M.; Mahrous, H. and Ghanaimy, G. (2009): Chemical, microbial counts and evaluation of biogenic amines during ripening of Egyptian soft domiati cheese made from raw and pasteurized buffaloes milk. Int. J. Dairy Sci. 4 (2): 80-90.

El-Zahar, K.M. (2014): Biogenic amines and microbiological profile of Egyptian cheeses. African J. Food Sci. 8(3): 130-139.

EOS (Egyptian Organization for Standardization and Quality Control) (1996): Detection of Poisons and Control, Report. pp.: 1796.

FDA (Food and Drug Administration) (2001): Food and drug administration hazards and controls. Guidance, $3^{\text {rd }}$ ed. Center of Food Safety and Nutrition, Washington, U.S.A.

Feldmen, D.; Hoffman, R. and Simpson, J. (2003): The solution for data analysis and presentation graphics. $2^{\text {nd }}$ ed. Abacus Lancripts, Inc. Barkeley, C.A. USA.

Fernández, M.; Linares, D.; Del Río, B.; Ladero, V. and Alvarez, M.A. (2007): HPLC quantification of biogenic amines in cheeses: correlation with PCR-detection of tyramineproducing microorganisms. J. Dairy Res. 74: 276-282.
Gardini, F.; Martuscelli, M. and Caruso, M.C., et al. (2001): Effects of $\mathrm{pH}$, temperature and $\mathrm{NaCl}$ concentration on the growth kinetics, proteolytic activity and biogenic amine production of enterococcus fecalis. Int. J. Food Microbiol. 64(1-2): 105-117.

Gonzalez de Llano, D.P.; Cuesta, P. and Rodriguez, A. (1998): Biogenic amine production by wild Lactococcal and Leuconostoc isolates. Le. Applied Microbiol. 26: 270-274.

Halász, A.; Baráth, Á. and Simon-Sarkadi, L., et al. (1994): Biogenic amines and their production by micro-organisms in food. Trends Food Sci. Tech. 5(2): 42-49.

Jarisch, R. (2004): Histamine- Intoleranz. Histamine und Seekrankheit. (Histamine intolerance. Histamine and motion sickness). Stuttgart, Germany: Georg Thieme Verlag. K G (in German).

Joosten, H.M.L.J. and Van Boekel, M.A.J.S. (1988): Conditions allowing the formation of biogenic amines in cheese for a study of the kinetics of histamine formation in an infected Gouda cheese. Neth. Milk Dairy J. 42: 329-357.

Joosten, H.M.L.J. and Northolt, M.D. (1987): Conditions allowing the formation of biogenic amines in cheese. 1. Decarboxylative properties of some non-starter bacteria. Neth. Milk Dairy J. 41: 259-280.

Krause, I.; Bockhardt, A.; Neckermann, H.; Henle, T. and Klostermeyer, H. (1995): Simultaneous determination of amino acids and biogenic amines by reversed- phase high performance liquid chromatography of the dabsyl derivatives. J. Chromatogr. A, 715: 67-79.

Maijala, R. and Erola, S. (2002): Biogenic amines. National Vet. and Food Res. Institute. Elsevier Sci. Ltd. Helsinki, Finland.

Maijala, R. and Erola, S. (2003): Biogenic amines. In: Encyclopedia of Dairy Sciences. Roginski, H., Fuquay, J.W. and Fox, P.F. (Eds.), New York: Academic Press pp.: 157-162.

Ma.Jannine, M. Vallejos; Laura, J. Pham and Virginia, L. Barraquio (2012): Biogenic amines in some natural and processed cheeses sold in Laguna province, Philippines. Philippine J. Sci. 141(1):111-115.

Maria, Izquierdo-Pulido; Mariné-Font, A. and Carmen, M. Vidal-Carou (2000): Effect of tyrosine on tyramine formation during beer fermentation. Food Chem. 70(3): 329-332.

Marino, M.M.; Maifreni, S.M. and Rondinini, G. (2000): The capacity of enterobacteriaceae species to produce biogenic amines in cheese. Let. Applied Microbiol. 31: 169-173.

Martuscelli, M.; Gardini, F. and Torriani, S. et al. (2005): Production of biogenic amines during the ripening of Pecorino Abruzzese cheese. Int. Dairy J. 15(6-9): 571-578. 
Muñoz, R. (2008): Bacterial biogenic amine production. Retrieved September 5, 2009 from http://www. scitopics.com/Bacterial biogenic amine production. Html.

Önal, A. (2007): Current analytical methods for determination of biogenic amines in food. J. Food chemistry, 103(4): 1475-1486.

Petridis, K.D. and Steinhart, H. (1996): Biogenic amine in der Hartkase - Produktion: II. Stufenkontroll- Studie einer standardisierten Emmentalerkase - Produktion. Dtsche. Lebensm - Rundsch. 5: 142-146.

Pinho, O.; Ferreira, I.; Mendes, E.; Oliviera, B. and Ferreira, M. (2001): Effect of temperature on evolution of free amino acid and biogenic amine contents during storage of Azeitao cheese. Food Chem. 75: 287-291.

Repka-Ramírez, M.S. and Baraniuk, J.N. (2002): Histamine in health and disease. J. Allergy Clin. Immunol. 17: 1-25.

Schneller, R.; Good, P. and Jenny, M. (1997): Influence of pasteurized milk, raw milk and different ripening cultures on biogenic amine concentrations in semi-soft cheeses during ripening. Z. Lebensm- Unters-Forsch A. 204: 265-272.

Shalaby, A.R. (1996): Significance of biogenic amines in food safety and human health. Food Res. Int. 29: 675-690.
Sharaf, O.M.; Abdalla, E.A.M. and Kawther El-shafei (1997): Closteridia, enterobacteriaceae, enterococci and its relation to biogenic amines content in Egyptian marketed Ras cheese. Egypt. J. Microbiol. 32: 129-140.

Silla, M.H.S. (1996): Biogenic amines: their importance in foods. Int. J. Food Microbiol. 29(2-3): 213-231.

Stratton, S.S.; Hutkins, R.W. and Taylor, S.L. (1991): Biogenic amines in cheese and other fermented foods. J. Food Prot. 54: 460-470.

Suzzi, G. and Gardini, F. (2003): Biogenic amines in dry fermented sausages. Int. J. Food Microbiol. 88: 41-54.

Ten Brink, B.; Damink, C.; Joosten, H.M.L.J. and Huisint-Veld, J.H.J. (1990): Occurrence and formation of biologically active amines in foods. Int. J. Food Microbiol. 11: 73-84.

Vale, S.R. and Gloria, M.B. (1997): Determination of biogenic amines in cheese. J. AOAC Int. 80(5): 1006-1012.

Wöhrl, S.; Hemmer, W.; Focke, M.; Rappersberger, $K$. and Jarisch, $R$. (2004): Histamine intolerance-like symptoms in healthy volunteers after oral provocation with liquid histamine. Allergy Asthma Proc. 25: 305-311.

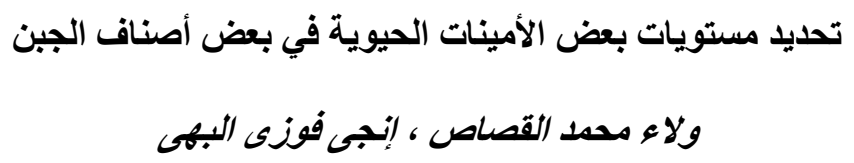

E-mail:w.elkasas@yahoo.com Assiut University web-site: www.aun.edu.eg

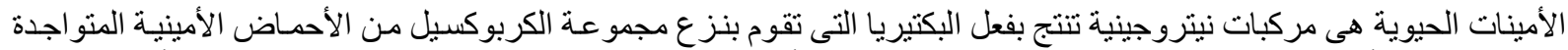

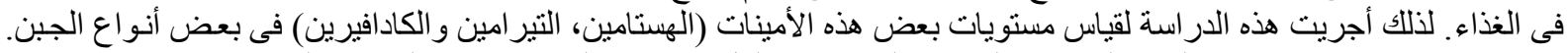

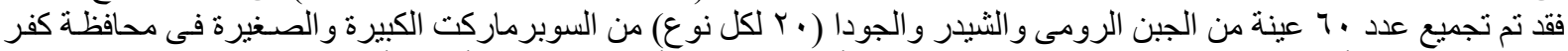

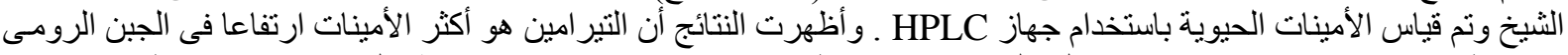

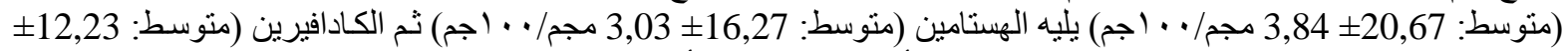

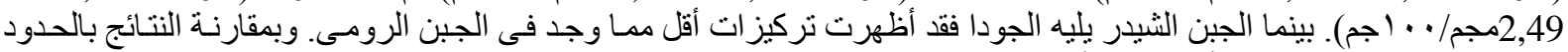

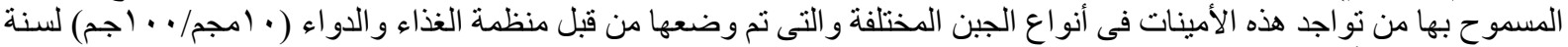

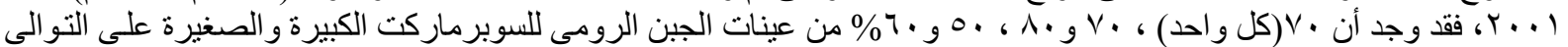

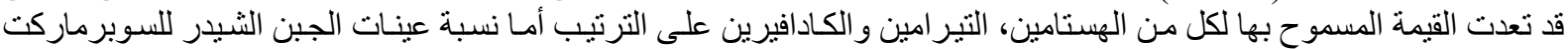

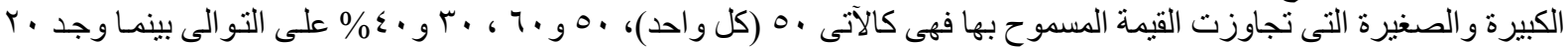

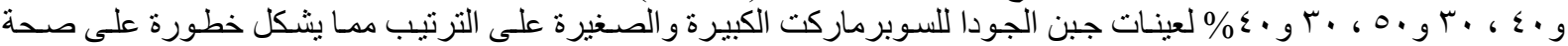

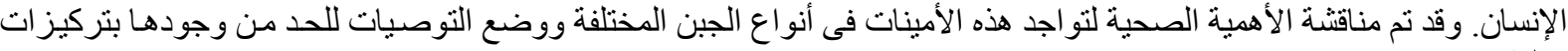

